\title{
Smartphone Addiction and the Use of Social Media among University Students
}

\section{Üniversite Ö̆̆rencilerinin Akıllı Telefon Bă̆ımlılı̆̆ ve Sosyal Ă̆ Kullanımı: Bir Durum Değerlendirmesi}

\section{Yasemin SANAL ${ }^{*}$ Ömer OZER **}

\begin{abstract}
This study was conducted to determine the prevalence of smartphone addiction, using the Smartphone Addiction Scale - Short Version (SAS-SV) among English language preparatory year students in a state university. It also aimed to determine which mobile applications are more popular among the participants. 164 students were given questionnaires, but seven were eliminated as not owning a smartphone. Statistical analysis was run for 157 students, of which 73 were girls and 84 boys, with an average age of 18.94. The analysis of the results showed that 28.8 percent of girls and 32.1 percent of boys were above the cut-off points. This constitutes $30.6 \%$ of the total participants that were among the risk group. There was no significant difference found based on gender, place of living or field of study. WhatsApp, Instagram, YouTube, Facebook and Snapchat were the most popular applications as over 50 percent of the participants used them. Study implications and future research directions were discussed.
\end{abstract}

Keywords: Smartphone Addiction, Social Media Use, Behavioral Addictions, Type of Usage, Habitual Behavior

$\ddot{O}_{z}: \mathrm{Bu}$ çalışma Akıllı Telefon Bağımlılı̆̆ı Ölçeği - Kısa Form (ATBÖ-KF) kullanarak, bir devlet üniversitesinin yabancı diller yüksekokulu hazırlık sınıfında öğrenim gören öğrencilerde, akıllı telefon bağımlılı̆̆ yaygınlığını belirlemek amacıyla yapılmıştır. Çalışma ayrıca hangi mobil uygulamaların katılımcılar arasında daha popüler olduğunu anlamayı amaçlamıştır. Bu doğrultuda, 164 öğrenciye anket uygulaması yapılmış ancak anketlerden 7 tanesi öğrencinin akı1lı telefon sahibi olmaması sebebi ile çalışma dışı bırakılmıştır. İstatistiksel analiz, yaş ortalamaları 18.94 olan, 73'ü kadın, 84'ü erkek 157 öğrenci üzerinden gerçekleştirilmiş̧ir. Analiz sonuçları kadın katılımcıların 28,8'i ve erkek katılımcıların \%32,1'inin kesme değerlerinin üzerinde kaldığını göstermiştir. Bu durum toplam katılımcıların \%30,6'sının risk altında olduğunu göstermektedir. Cinsiyet, ikamet ve bölüm değişkenlerine göre istatiksel anlamlı bir fark bulunmamıştır. Katılımcıların \%50'sinden fazlası tarafından kullanılan en popüler akıllı telefon uygulamalarının sırasıyla Whatsapp, Instagram, YouTube, Facebook ve Snapchat olduğu görülmüştür. Gelecek araştırmalara yönelik öneriler geliştirilmiştir.

Anahtar sözcükler: Akıllı Telefon Bağımlılı̆̆ı, Sosyal Medya Kullanımı, Davranışsal Bağımlılıklar, Kullanım Amacı, Otomatikleşmiş Davranış

\footnotetext{
* Asst. Prof., Adana Science and Technology University, Faculty of Humanities and Social Sciences, Department of Psychology, Adana. yaseminsanal@gmail.com

** PhD, Adana Science and Technology University, School of Foreign Languages, Department of Translation and Interpreting Studies, Adana. ozeromer.tr@gmail.com
} 
The last decades of the twentieth century brought rapid and extraordinary changes in the world of technology. The advent of globalization and practical communication systems signaled the alteration of our world: becoming an increasingly wired world (Kenning 2007). One of the most popular forms of these systems are mobile phones as they are portable and practical regardless of time and space. In subsequent years smartphones widely replaced mobile phones (Lee 2016). Their larger screen size and portability enabled users to do a plethora of functions without being confined to a certain place (Samaha \& Hawi 2016).

Smartphones are not just communication tools like mobile phones but also became one of the main platforms for information acquisition for modern people. At the end of 2016 there were 2.1 billion smartphone users in the world and this total is forecasted to reach 2.87 billion users by 2020 (Statista 2017a). In Turkey, 75.06 million mobile phone users were registered by 2016 . Turkey ranked of European countries top in the average time spent on mobile phones (Information Communication Technologies Agency 2017). People stay connected and search on their mobile phones through tools such as mobile applications and mobile websites. The market for mobile applications is getting larger by the day. The market scale of mobile applications has increased significantly with the breakout of smartphone market (Hui-Yi \& Ling-Yin 2010). Smartphones offer users a number of downloadable applications through application markets. The three main application stores in popularity for customers to download new applications are Google Play for Android users, App Store for IOS users and Windows Market, respectively, December 2016 (Statista 2016b). There is a noticeable increase in both the development and investment in applications all over the world. By March 2017, there were 5.7 million free or paid applications for users to download in these leading application stores. A striking figure from May 2015, showing the distinction between free and paid applications, indicated that, of 1.6 million available apps on Google Play; the free applications constituted 68.8 percent (Statista 2016a). Smartphone users download applications because they are more of a necessity due to their great functionality.

When functions are considered, both communication and information acquisition are supported by smartphones. In addition to the basic functions of calling and texting by mobile phones, smartphones also offer their users a number of functions such as computing, navigation, following and sharing photographs/videos, instant messaging, and internet (Gill, Kamath \& Gill 2012) through either pre-installed applications by the manufacturers or through downloadable applications from application platforms. A wealth of material regarding the subject of providing real-time information on smartphones can be found in the literature. Users can utilize a wide variety of social networking sites to obtain real-time information (Lee 2016). Griffiths (2013) defined social networking sites (SNSs) as virtual communities in which people can create profiles and interact with real-life friends and make new friends based upon shared interests. The results from a study by Lee (2016) showed that 44.9 percent of the respondents use their smartphones for instant messaging, for SNS's and for messenger services.

In the last decade, the regular use of SNS's has risen considerably and recent evidence has shown that people contacting their social network online can lead to the excessive use of social networking sites (Griffiths 2013). A study by Salehan and Negahban (2013) showed that mobile social networking applications significantly increase the risk of mobile addiction. A dilemma here is that the ubiqutiousness of smartphones makes it possible for individuals to stay updated on social media. Facebook is one of the social networking applications which individuals can use excessively. Allen (2017) reported that WhatsApp is the second most used application after Facebook. QQ, WeChat, QZone, Instagram, Tumblr, Twitter and Snapchat are placed in the list, 
respectively. Another study, conducted with 441 students at library and information technology in Egypt found that e-mail, Facebook and Twitter were the most popular applications, followed by YouTube, WhatsApp and Kik (Mansour 2016).

As smartphones have become more available, individuals become more reliant on technology (Jordaan \& Surujlal 2013). When internet use by age is considered, although all age groups have progressively increased in their use of the internet, the 18-29 age group has always ranked first because that age range has the most internet use (Pew Research Center 2012). And in parallel, according to Bianchi and Phillips (2005), when compared to older people, young people are more prone to the problematic use of the mobile phone. It is mentioned by Cholitiz (2010) that attributes and characteristics of mobile phones attract and incite smartphone use especially in adolescence. Similarly, university students are a risk group for problematic internet usage since they can be considered techno-savvy (Shaw \& Fairhurst 2008). Since smartphones are connected to the internet services $24 / 7$, they become one of the main tools that increases university students' problematic internet use. When gender is considered, different results from different countries can be found in the literature. In a study conducted in Thailand, Kawasaki et al. (2006) reported that of male and female high school students, and male and female university students; the female high school students have the highest mobile phone dependence tendency. Another study conducted in Madrid also concluded that intensive phone use was associated with females (Sanchez-Martinez \& Otero 2009). A study conducted with 416 university students by Emanuel et al. (2016) suggested that female students were more connected to their mobile phones psychologically and emotionally, but males seemed to check their mobile phones more often. According to Şar's (2013) study, problematic phone use is more by male teenagers than by females.

Smartphones have influenced almost all aspects of human life. It has also drastically altered the behaviours of individuals, in a positive or a negative way. A smart phone can affect the way individuals acquire information by means of its ubiquitousness. Applications can be used in mobile devices so as to support real-time information sharing such as e-commerce, bookingtickets, mobile banking, and navigation. For example, the market of virtual shopping has gradually grown larger over past decades and has become an alternative to traditional shopping (Agcadag 2014). These aforementioned functions and so on become advantages in the daily lives of individuals since they can help them to save time and energy. Smartphones do serve purposes not only in daily life but also for areas from healthcare to education. Smartphones occupy a crucial role in healthcare settings. Many applications can be found in application stores from diagnosis to medical calculations, chronic disease management to sleeping aids; and they are not only for healthcare professionals but also for medical/nursing students and patients as well (Mosa et al., 2012). Some mobile applications even help to prevent emotional mental health problems (Bakker et al. 2016). A focus study group with students in higher education concludes that using mobile devices and social networking allows them to engage more with the course content and this helps the learning to occur regardless of location (Gikas \& Grant 2013). Mobile devices may also help students follow the content of the courses in the form of distance learning, as they can be used anywhere, at any time (Farley et al. 2015). In so doing, absentees can get the opportunity to compensate for the content they missed by consulting the online content via smartphones. In Ozer's (2017) study, a statistically significant difference was found, in favor of the students using smartphones, both in academic achievement and in cognitive load.

Unfortunately, despite its apparent advantages, uncontrolled and excessive use of smartphones may also be associated with potentially harmful behaviours. For example, the point when 
problematic social media use arises is when people consider social networking an indispensable way to relieve stress, loneliness, or depression (Griffiths 2013). From that time onwards, they becoming more absorbed in SNS's and this excessive use eventually causes many social and physical problems. A review article on electronic media use and sleep presents a conclusion that even though the mechanisms are not clear, electronic media use by children and adolescents have negative effects on sleep (Cain \& Gradisar 2010). Another study conducted with adults in Sweden suggested that high mobile phone use was associated with sleep disturbance and symptoms of depression (Thomee et al. 2011). Darçın et al.'s study (2016) indicated a relationship between social anxiety, loneliness and excessive use of smartphones. They argued that, excessive use of smartphones can be either self-treatment (a way of socialization) for loneliness or loneliness is a possible consequence of excessive smartphone use. Also, excessive use of smartphones can be seen as one of main sources of distraction during performing tasks needing mental concentration (Gill, Kamath \& Gill 2012). For example, a study shows that using mobile phones even in hands-free mode reduces visual attention while driving (Barkana $e t$ al. 2004). While it was mentioned as an advantage since students may benefit from smartphones in distance learning or to engage more with the content of the course, smartphones may also drive users to distraction during face-to-face classes that need mental concentration. Much research has suggested that internet-based mobile applications may distract students' attention away from the course content (Rogers 2011; Vaughan \& Lawrence 2013). Based on these findings, it probably won't be wrong to say that despite the advantages, the intensive use of such technology may cause problematic usage and even addiction.

In recent years, we began to become familiar with addiction attached to food, gambling, the internet, sex, shopping, exercise, work... etc. Gambling has found itself a place under NonSubstance-Related Disorders and Internet Gaming Disorder under Other Conditions That May Be a Focus of Clinical Attention in the Fifth Edition of the Diagnostic and Statistical Manual of Mental Disorders (DSM-V). But the aforementioned concepts are all being discussed in the current literature although most of them haven't found a place yet in the DSM. In general, all of these behavioral addiction concepts are very similar to substance related disorders. They have common patterns such as persistent use of the addicted behavior despite the negative consequences; unsuccessful attempts to limit the behavior; disruptions of daily life due to the related behavior; or negative mood changes when the addictive behavior is not available. Griffiths (1996) proposed the concept of technological addictions, which is operationally defined as non-chemical addiction involving human-machine interaction. It can be implied that smartphone addiction is like a sub-branch of technological addictions along with video game addiction, online gambling addiction, online sex addiction and social networking addiction. Smartphone addiction can be defined as a pattern of smartphone use with addiction.

\section{Statement of the problem}

Like substance addictions, behavioral addictions can pose a risk to health. As smartphones are becoming increasingly popular among young people, as well as in other age groups, these devices can also be detrimental to health. As Lee (2016) has pointed out, young people use their smartphones primarily for SNS's purposes. In this study, our aim was to determine the prevalence of potential smartphone addiction and also to determine which mobile applications are more popular among university students. Specific research questions to be addressed in this study are as follows:

(1) What is the nature of smartphone addiction among the respondents?

- How frequent is smartphone addiction among the respondents? 
- Is 'gender' a significant indicator for smartphone addiction based on the SAS-SV scores?

- Is there any relationship between smartphone addiction scores and place of living?

- Is there any relationship between smartphone addiction and field of study?

(2) How popular are mobile phone applications among the respondents?

\section{Methodology}

\section{Participants and Procedure}

A non-random method of convenience sampling was used to recruit participants, who were 164 students attending compulsory year-long English language preparatory classes at Adana Science and Technology University. However, since seven of those students did not own a smartphone, their data were excluded from the analysis. As such, the questionnaire responses of 157 students ( 73 females) were analyzed in this study. The average age of this sample was 18.94 years. The aim and nature of the study were all explained to the respondents and they were assured that their answers would be treated with anonymity. Participation in the study was voluntary and the respondents took approximately 15 minutes to complete the questionnaire.

\section{Data Collection Tools}

\section{Socio-demographic Questionnaire}

A closed-ended questionnaire was used to gather information about the participants' age, gender, living arrangements, educational background and lifestyle-related habits.

\section{Mobile Applications Usage Form}

The participants responded to the form by selecting the mobile applications they used actively on their smartphones. From the wide variety of applications available, only the most popular applications from the Google Play Store and AppStore were used in this form, in accord with the research aims and the related literature. Participants identified whether or not they used each of the most popular mobile applications.

\section{Smartphone Addiction Scale-Short Version (SAS-SV)}

A 10-item self-report measure of smartphone addiction, which was developed by Kwon et al. (2013), was completed by the participants. This scale was adapted and validated to Turkish for university students by Noyan et al. (2015). The Cronbach's Alpha coefficient of the Turkish version of the SAS-SV was 0.87 and consisted of one factor. In this study, the reliability test of the SAS-SV yielded a Cronbach's alpha of 0.91. The SAS-SV is scored on a 6-point Likert scale ranging from 1 (strongly disagree) to 6 (strongly agree). High scores on the SAS-SV indicate high risk of smartphone addiction. The cut-off values for high versus low risk of smartphone addiction from the Turkish version of the SAS-SV have not been suggested in previous work. However, in Kwon et al.'s study in a Korean sample, the cut-off values were defined as 33 for females and 31 for males. Above these values, participants were considered to be at a high risk of smartphone addiction.

\section{Analyses}

The data collected was entered and analyzed using SPSS. In the first part of the analysis, frequency distributions for the participants' demographic characteristics were generated. Between-group differences were determined by t-tests for gender differences. The skewness ranged from .339 to .938 and kurtosis ranged from -1.174 to -.211 . A histogram and a normality 
plot were assessed and showed the assumption of normality was met. The Levene's test for homogeneity of variance was performed on all dependent variables and indicated that group variances were indeed equal. Additionally, a one-way ANOVA was used to determine whether there was a statistically significant difference in SAS-SV scores between the groups formed by field of study and students' living arrangements. The 0.05 level of significance was used throughout this research.

Since the cut-off values of the SAS-SV have not previously been reported in Turkey, the cut-off values reported by Kwon et al. (2013) based on their work with the SAS-SV in South Korea, were adopted. As such, the cut-off values used in this study were 31 in males and 33 in females.

\section{Results}

To find an answer to the first research question, participants responded to 10 questions, on a sixpoint scale, that highlights the current situation of smartphone addiction of this sample. The SAS-SV total scores were then calculated. The data collected from the scale is presented in Table 1.

\begin{tabular}{|c|c|c|c|c|c|c|c|}
\hline & \multirow[t]{2}{*}{ Items } & \multicolumn{2}{|c|}{ Overall } & \multicolumn{2}{|c|}{ Girls } & \multicolumn{2}{|c|}{ Boys } \\
\hline & & Mean & SD & Mean & SD & Mean & SD \\
\hline 1 & $\begin{array}{l}\text { Missing planned work due to smartphone } \\
\text { use. }\end{array}$ & 2.57 & 1.55 & 2.59 & 1.46 & 2.55 & 1.62 \\
\hline 2 & $\begin{array}{l}\text { Having a hard time concentrating in class, } \\
\text { while doing assignments, or while working } \\
\text { due to smartphone use. }\end{array}$ & 2.76 & 1.55 & 2.81 & 1.48 & 2.71 & 1.63 \\
\hline 3 & $\begin{array}{l}\text { Feeling pain in the wrists or at the back of } \\
\text { the neck while using a smartphone. }\end{array}$ & 2.62 & 1.7 & 2.90 & 1.68 & 2.38 & 1.69 \\
\hline 4 & $\begin{array}{l}\text { Won't be able to stand not having a } \\
\text { smartphone. }\end{array}$ & 2.86 & 1.81 & 2.97 & 1.88 & 2.76 & 1.77 \\
\hline 5 & $\begin{array}{l}\text { Feeling impatient and fretful when I am not } \\
\text { holding my smartphone. }\end{array}$ & 2.56 & 1.69 & 2.73 & 1.83 & 2.42 & 1.55 \\
\hline 6 & $\begin{array}{l}\text { Having my smartphone in my mind even } \\
\text { when I am not using it. }\end{array}$ & 2.60 & 1.63 & 2.59 & 1.62 & 2.61 & 1.65 \\
\hline 7 & $\begin{array}{l}\text { I will never give up using my smartphone } \\
\text { even when my daily life is already greatly } \\
\text { affected by it. }\end{array}$ & 2.75 & 1.72 & 2.86 & 1.74 & 2.64 & 1.71 \\
\hline 8 & $\begin{array}{l}\text { Constantly checking my smartphone so as } \\
\text { not to miss conversations between other } \\
\text { people on Twitter or Facebook. }\end{array}$ & 2.31 & 1.48 & 1.23 & 1.48 & 2.38 & 1.50 \\
\hline 9 & $\begin{array}{l}\text { Using my smartphone longer than I had } \\
\text { intended. }\end{array}$ & 3.02 & 1.69 & 3.12 & 1.64 & 2.93 & 1.74 \\
\hline 10 & $\begin{array}{l}\text { The people around me tell me that I use my } \\
\text { smartphone too much. }\end{array}$ & 2.77 & 1.71 & 3.14 & 1.81 & 2.45 & 1.57 \\
\hline
\end{tabular}

The overall mean score from the scale was 2.68 with a standard deviation of 1.23. In addition to the mean scores, the respondents' SAS-SV scores were also compared to the established cut-off values. Results indicated that 21 (28.8\%) out of the 73 females, had scores above the cut-off value, indicating they were at high risk of smartphone addiction. Additionally, 27 (32.1\%) out of the 84 male participants had scores that were above the pre-determined cut-off value. The participants whose SAS-SV scores were above the cut-off were spotlighted and the range (min. 35 and max. 59 for females; min. 31 and max. 60 for males) and arithmetic mean (44.48 \pm 6.61 
for females; $40.48 \pm 8.57$ for males) for this data were calculated. The 48 respondents who were found to be above the cut-off values constitute $30.6 \%$ of the total sample and exhibit a higher risk of problematic smartphone use.

When SAS-SV scores were considered in relation to the socio-demographic characteristics of the sample, it was found that the females' mean total was $27.97 \pm 12.15$ and the males' total score was $25.85 \pm 12.43$. Participants' SAS-SV total score was calculated $26.83 \pm 12.31$. In order to examine whether there are any significant differences in terms of gender, age, field of study and place of living in the risk of smartphone addiction, an independent samples t-test and one-way ANOVA were conducted. Group means together with the results of statistical tests are shown in Table 2.

\begin{tabular}{|c|c|c|c|c|}
\hline Variable & & $\mathbf{N}$ & SAS-SV & p. \\
\hline & & Mean \pm SD & Mean \pm SD & \\
\hline Age & & & $18.94 \pm 0.96$ & \\
\hline \multirow[t]{2}{*}{ Sex } & Female & 73 & $2.79 \pm 1.21$ & \multirow[t]{2}{*}{.883} \\
\hline & Male & 84 & $2.58 \pm 1.24$ & \\
\hline \multirow[t]{3}{*}{ Field of Study } & Engineering & 102 & $2.79 \pm 1.27$ & \multirow{3}{*}{.330} \\
\hline & Business & 42 & $2.46 \pm 1.04$ & \\
\hline & Tourism & 13 & $2.57 \pm 1.42$ & \\
\hline \multirow[t]{5}{*}{ Place of Living } & Living with parents at home & 89 & $2.52 \pm 1.12$ & \multirow[b]{2}{*}{.338} \\
\hline & Dormitory & 52 & $2.91 \pm 1.38$ & \\
\hline & Living with partner(s) at an apartment & 6 & $3.31 \pm 1.55$ & \\
\hline & Living with relatives (not paying rents) & 5 & $2.04 \pm 0.77$ & \\
\hline & Living alone at an apartment & 5 & $3.00 \pm 0.89$ & \\
\hline
\end{tabular}

No significant difference in the scores for females $(M=2.79)$ and males $(M=2.58)$ were observed $\mathrm{t}(155)=1.073, \mathrm{p}=.883$. Similarly, ANOVA results for field of study and living arrangements showed no significant group differences in participants' SAS-SV scores.

In order to answer the second research question, 157 students who owned smartphones were asked whether or not they used the following applications. The summary statistics of the participants' responses are presented in Table 3.

Table 3. Social Media Applications by Usage Rate

\begin{tabular}{|l|c|c|c|c|}
\hline Application & Yes, I use this app & \multicolumn{2}{|c|}{ No, I do not use this app } \\
\hline WhatsApp & $\boldsymbol{f}$ & $\boldsymbol{\%}$ & $\boldsymbol{f}$ & $\mathbf{\%}$ \\
\hline Instagram & 147 & 93.6 & 10 & 6.4 \\
\hline Video sharing apps such as YouTube or Vimeo & 134 & 85.4 & 23 & 14.6 \\
\hline Facebook & 122 & 77.7 & 35 & 22.3 \\
\hline Snapchat & 104 & 66.2 & 53 & 33.8 \\
\hline Twitter & 83 & 52.9 & 74 & 47.1 \\
\hline Swarm & 70 & 44.6 & 87 & 55.4 \\
\hline Blog-publishing apps such as Tumblr/Blogger & 26 & 16.6 & 131 & 70.1 \\
\hline
\end{tabular}




\begin{tabular}{|l|c|c|c|c|}
\hline Periscope & 17 & 10.8 & 140 & 89.2 \\
\hline Foursquare & 14 & 8.9 & 143 & 91.1 \\
\hline Pinterest & 7 & 4.5 & 150 & 95.5 \\
\hline LinkedIn & 6 & 3.8 & 151 & 96.2 \\
\hline Tinder & 3 & 1.9 & 154 & 98.1 \\
\hline
\end{tabular}

Participants with smartphones were given SAS-SV forms alongside the survey of Smartphone Apps. As can be seen from Table 3, WhatsApp is at the top of the list as the app that $93.6 \%$ of participants use. This is followed by Instagram with a percentage of 85.4. The other applications in the top five are YouTube, Facebook and Snapchat, respectively. Tinder was by far the least used application in the present study.

\section{Discussion and Conclusion}

Internet use has become an inseparable part of student life. It has now become a routine act of daily life to use smartphones to browse the web in search of information. Unfortunately though, for some students, smartphones are not just an integral part of their life but also a potential source of addiction.

From the current study, it can be concluded that $30.6 \%$ of participants are at a high risk of smartphone addiction based upon their SAS-SV scores. This figure suggests that smartphone use is becoming a non-negligible problem among students. Samaha and Hawi (2016), who also used the SAS-SV instrument, found that the prevalence of students with a high risk of excessive smartphone use was $44.6 \%$. The literature reveals that different assessment instruments exist for the measurement of smartphone addiction. Long et al. (2016) have studied problematic mobile phone use among Chinese undergraduates and found the prevalence of problematic smartphone use to be $21.3 \%$. Pearson and Hussain (2016) conducted an online survey in the UK and found that only $13.3 \%$ of their sample meet smartphone addiction criteria. Since different instruments are used in different cultures, the results appear to diverge markedly. Based upon these different percentages, it should be kept in mind that cultural differences may apply. Unfortunately more data from Turkish subjects using other measures of smartphone addition are needed for more direct comparisons to be made.

One of the concerns of the current work was whether gender was an indicator of smartphone addiction. When the general mean scores gathered from the SAS-SV were analyzed, results suggest that gender does not have an effect on problematic smartphone use. Having said that, when the scores of male and females who were placed over the cut-off scores were compared, it was seen that female scores were distributed a little higher than those of males. It was mentioned that different results exist in the literature related to gender differences in smartphone addiction in different cultures. As for Turkey, the current study contradicts the findings of Şar (2013), in which problematic mobile phone use was found more in male teenagers than in their female counterparts. But the present study's findings are compatible with Kuyucu's (2017) study on university students which found no significant relation between smartphone addiction and gender. Even though the current study found no significant difference in smartphone addiction based upon gender, it should be noted that when individuals' attributions and attachment levels to their smartphones and applications are studied thoroughly in relation to gender, the results may vary.

Results of a one-way analysis of variance showed no significant difference in smartphone addiction scores based on the field of study. In contrast, Abu-Jedy (2008) reported that students 
studying in humanities departments tend to use their mobile phones more problematically than students majoring in the natural sciences (Abu-Jedy 2008). However, unlike the students in that study, the students in the present study were registered to different departments but had not yet started their majors. At the time of this study the students were all studying together in a yearlong English language preparatory programme.

Smartphone application use was also investigated in the present study. Students were asked to indicate which of the currently most popular applications they actively use. The top three mobile phone applications were WhatsApp, Instagram and YouTube. Facebook and Snapchat followed the top three with more than $50 \%$ of participants reporting that they actively use these applications. These results are found to be parallel to, but not exactly the same as, those in the relevant literature. Pearson and Hussain (2016) indicated that SNS applications are the most popular applications, followed by instant messaging, and music, photo and video applications. They also mentioned that dating applications are used by only $2 \%$ of their participants, which is similar to the findings of the present study. A recent study conducted in Turkey by Kuyucu (2017) also asked university students about the smartphone applications that they use and results showed that Instagram, Twitter and Facebook are the most popular applications amongst participants. This slightly different result may in part have resulted from the larger sample size in Kuyucu's (2017) study.

In conclusion, problematic smartphone use is becoming a non-negligible issue among students in Turkey. Even though smartphones may ease the life of university students with their multifarious functions and applications, they pose a potential risk of addiction. Even though the excessive use of smartphones can provoke certain negative behaviors in individuals, this alone, is insufficient to prove their addictive power. Preventive strategies against excessive smartphone use should be taken into consideration. Medical centers and psychological counseling centers at universities should inform students about the possible consequences of problematic smartphone use and provide help in reducing or preventing these negative consequences.

\section{Limitations and Future Research}

Some limitations should be taken into consideration in respect to the present study. Firstly, due to the nature of a questionnaire as data collection method, the answers are based on only selfreports which may influence the results with response bias or errors. Secondly, the study was limited because of the small sample size and convenience sampling. Thirdly, the cut-off points per gender to classify problematic smartphone use were not determined for the Turkish population in the Turkish validation study, so the Korean cut-off scores were taken into consideration in the present study. Although the number of participants was appropriate for the aim of the present study, future studies may be conducted using larger and more diverse samples due to the abovementioned reasons. Current research highlights smartphone use amongst university students but it alone does not provide any causality on smartphone addiction. So, another suggestion for future studies is to focus on the psychological and sociological indicators of smartphone addiction.

\section{REFERENCES}

Abu-Jedy A. (2008). "Mobile Phone Addiction and Its Relationship with Self-Disclosure Among Sample of Students from University of Jordan and Amman Al-Ahliyya University". Jordan Journal of Educational Science 4/2 (2008) 137-50.

Agcadağ İ. (2014). "Sanal Alışveriş". MJH 4/1 (2014). Doi: 10.13114/MJH.201416420 
Allen R. (2017, February). “Top Social Network Sites by Number of Active Users 2017”. Retrieved April 09, 2017, from http://www.smartinsights.com/social-media-marketing/social-media-strategy/newglobal-social-media-research/attachment/top-social-network-sites-by-number-of-active-users-2017/

Bakker D., Kazantis N., Rickwood D. \& Rickard N. (2016). "Mental Health Smartphone Apps: Review and Evidence-Based Recommendations for Future Developments". JMIR Mental Health 3/1 (2016). doi: 10.2196/mental.4984

Barkana Y., Zadok D., Morad Y. \& Avni I. (2004). Visual Field Attention Is Reduced by Concomitant Hands-Free Conversation on a Cellular Telephone. American Journal of Ophthalmology 138/3 (2004) 347-353.

Bianchi A. \& Phillips J. G. (2005). "Psychological Predictors of Problem Mobile Phone Use". Cyberpsychology \& Behavior 8/1 (2005) 39-51.

Cain N. \& Gradisar M. (2010). "Electronic Media Use and Sleep in School-Aged Children and Adolescents: A Review". Sleep Medicine 11/8 (2010) 735-742. Doi: 10.1016/j.sleep.2010.02.006

Choliz M. (2010). "Mobile Phone Addiction: A Point of Issue". Addiction 105/2 (2010) 373-374. Doi: $10.1111 / \mathrm{j} .1360-0443.2009 .02854$.

Noyan C. O., Enez Darcin A., Kose S., Nurmedov S., Y1lmaz O. \& Dilbaz N. (2016). "Smartphone Addiction and Its Relationship with Social Anxiety and Loneliness". Behavior \& Information Technology 35/7 (2016) 520-525.

Emanuel R., Bell R., Cotton C., Craig J., Drummond D., Gibson S., Harris A., Harris M., Hatcher-Vance C., Jones S. \& Lewis J. (2015). "The Truth about Smartphone Addiction". College Student Journal 49/2 (2015) 291-299.

Farley H., Angela M., Johnson C., Carter B., Lane M., Midgley W., Hafeez-Baig A., Dekeyser S. \& Koronios A. (2015). "How Do Students Use Their Mobile Devices to Support Learning? A Case Study from an Australian Regional University". Journal of Interactive Media in Education 1/2 (2015). Doi: $10.5334 /$ jime.ar

Gill P. S., Kamath A. \& Gill T. S. (2012). "Distraction: An Assessment of Smartphone Usage in Health Care Work Settings". Risk Management and Healthcare Policy 5 (2012). Doi: 10.2147/RMHP.S 34813

Gikas J. \& Grant M. M. (2013). "Mobile Computing Devices in Higher Education: Student Perspectives on Learning with Cellphones, Smartphones \& Social Media”. The Internet and Higher Education 19 (2013) 18-26.

Griffiths M. D. (1996). "Gambling on the Internet: A Brief Note". Journal of Gambling Studies 12/4 (1996) 471-473.

Griffiths M. D. (2013). "Social Networking Addiction: Emerging Themes and Issues". Addiction Research \& Therapy 4 (2013). Doi: 10.4172/2155-6105.1000e118

Hui-Yi H. \& Ling-Yin S. (2010). "Uses and Gratifications of Mobile Application Users". Electronics and Information Engineering (ICEIE), International Conference, Kyoto, V1 (2010) 315-319. Retrieved 23 June 2017, from http://ieeexplore.ieee.org/document/5559869/

Information and Communication Technologies Authority [Bilgi Teknolojileri ve İletişim Kurumu] (2017). Türkiye Elektronik Haberleşme Sektörü. Retrieved April 07, 2017, from https://www.btk. gov.tr/ File/?path=ROOT\%2f1\%2fDocuments\%2fSayfalar\%2fPazar_Verileri\%2f2016Q..pdf

Jordaan D. B. \& Surujlal J. (2013). "Social Effects of Mobile Technology on Generation Y Students". Mediterranean Journal of Social Sciences 4/11 (2013). Doi: 10.5901/mjss.2013.v4n11p282

Kawasaki N., Tanei S., Ogata F., Burapadaja S., Loetkham C., Nakamura T. \& Tanada S. (2006). "Survey on Cellular Phone Usage on Students in Thailand". Journal of Physiological Anthropology 25/6 (2006) 377-382.

Kenning M-M. (2007). ICT and Language Learning: From Print to the Mobile Phone. Great Britain 2007.

Kuyucu M. (2017). "Gençlerde Akıllı Telefon Kullanımı ve Akıllı Telefon Bağımlılığı Sorunsalı: 'Akıllı Telefon (Kolik)' Üniversite Gençliği”. Global Media Journal TR Edition 7/14 (2017) 320-351

Kwon M., Kim D. J., Cho H. \& Yang S. (2013). "The Smartphone Addiction Scale: Development and Validation of a Short Version for Adolescents". PloS One 8/12 (2013) 1-7. Doi: 10.1371/journal. 
pone. 0083558

Long J., Liu T. Q., Liao Y. H., Qi C., He H. Y., Chen S. B. \& Billieux J. (2016). "Prevalence and Correlates of Problematic Smartphone Use in a Large Random Sample of Chinese Undergraduates". BMC Psychiatry 16/1 (2016) 408. Doi: 10.1186/s12888-016-1083-3

Lee S. (2016). "A Study on the Effect of Communication Functioning of Smartphones on Information Acquisition: The Case of South Korea". Journal of Information Science Theory and Practice 4/3 (2016) 28-42.

Mansour E. (2016). "Use of Smartphone Apps Among Library and Information Science Students at South Valley University, Egypt”. The Electronic Library 34/3 (2016) 371-404.

Mosa A. S. M., Yoo I. \& Sheets L. (2012). “A Systematic Review of Healthcare Applications for Smartphones". BMC Medical Informatics and Decision Making 12/1 (2012) 67.

Noyan C. O., Enez Darçın A., Nurmedov S., Yılmaz O. \& Dilbaz N. (2015). “Akıllı Telefon Bağımlılığı Ölçeğinin Kısa Formunun Üniversite Öğrencilerinde Türkçe Geçerlilik ve Güvenilirlik Çalışması”. Anadolu Psikiyatri Dergisi 16/1 (2015) 73-81.

Ozer O. (2017). The Effect of Mobile-assisted Language Learning Environment on EFL Students' Academic Achievement, Acceptance of Mobile Learning Devices and Cognitive Load. Unpublished Doctoral Dissertation. Mersin University, Mersin 2017.

Pearson C. \& Hussain Z. (2016). "Smartphone Addiction and Associated Psychological Factors". Addicta: The Turkish Journal of Addictions 3/2 (2016) 193-207.

Pew Research Center (2012). “Internet User Demographics”. Retrieved May 09, 2017, from http://www. pewinternet.org/fact-sheet/internet-broadband/

Rogers K. D. (2011). Mobile Learning Devices. USA 2011.

Salehan M. \& Negahban A. (2013). "Social Networking on Smartphones: When Mobile Phones Become Addictive". Computers in Human Behavior 29/6 (2013) 2632-2639.

Samaha M. \& Hawi N. S (2016). "Relationships among Smartphone Addiction, Stress, Academic Performance, and Satisfaction with Life". Computers in Human Behavior 57 (2016) 321-325.

Sánchez-Martínez M. \& Otero A. (2009). "Factors Associated with Cell Phone Use in Adolescents in the Community Of Madrid (Spain)". CyberPsychology \& Behavior 12/2 (2009) 131-137.

Statista (2016a). "Distribution of Free and Paid Android Apps in The Google Play Store from 2009 to 2015". Retrieved April 29, 2017, from https://www.statista.com/statistics/266211/distribution-offree-and-paid-android-apps/

Statista (2016b). "Global Mobile OS Market Share in Sales to End Users From 1st Quarter 2009 to 1st Quarter 2016”. Retrieved April 29, 2017, from https://www.statista.com/statistics/266136/globalmarket-share-held-by-smartphone-operating-systems/

Statista (2017a). "Number of Smartphone Users Worldwide 2014-2020”. Retrieved April 07, 2017, from https://www.statista.com/statistics/330695/number-of-smartphone-users-worldwide/

Statista (2017b). “Number of Apps Available in Leading App Stores as of March 2017”. Retrieved April 07,2017; from https://www.statista.com/statistics/276623/number-of-apps-available-in-leading-appstores/

Shaw S. \& Fairhurst D. (2008) "Engaging a New Generation of Graduates". Education + Training 50/5 (2008) 366-378. Doi: 10.1108/00400910810889057

Şar A. H. (2013) "Ergenlerde Yalnızlık ve Mobil Telefon Bağımlılığı Probleminin Bazı Değişkenlere Göre İncelenmesi”. International Journal of Social Science 6/2 (2013) 1207-1220.

Thomée S., Härenstam A. \& Hagberg M. (2011). "Mobile Phone Use and Stress, Sleep Disturbances, and Symptoms of Depression among Young Adults - A Prospective Cohort Study". BMC Public Health 11/1 (2011). Doi: 10.1186/1471-2458-11-66

Vaughan N. \& Lwrence K. (2013). "Investigating the Role of Mobile Devices in a Blended Pre-Service Teacher Education Program”. Canadian Journal of Higher Education 43/3 (2013) 56-77. 